\title{
Application of platinum-cobalt-boron as the anode material for sodium borohydride-hydrogen peroxide fuel cells
}

\author{
Aldona Balčiūnaite $\dot{~}^{*}$, \\ Zita Sukackiene் ${ }^{1}$, \\ Loreta Tamašauskaitė-Tamašiūnaitè $\dot{e}^{1}$ \\ Rimantas Vaitkus ${ }^{2}$, \\ Eugenijus Norkus ${ }^{1}$ \\ ${ }^{1}$ Department of Catalysis, \\ Center for Physical Sciences and Technology, \\ Saulètekio Ave. 3, 10257 Vilnius, Lithuania \\ ${ }^{2}$ Faculty of Chemistry and Geosciences, \\ Vilnius University, \\ Naugarduko St. 24, \\ 03225 Vilnius, Lithuania
}

The electroless deposition and galvanic displacement methods were used for the fabrication of cobalt-boron $(\mathrm{CoB})$ catalysts modified with small amounts of platinum crystallites in the range of 9.8 to $14.4 \mu \mathrm{g}_{\mathrm{Pt}} \mathrm{cm}^{-2}$. The prepared catalysts were studied as the anode materials for direct borohydride-hydrogen peroxide $\left(\mathrm{NaBH}_{4} / \mathrm{H}_{2} \mathrm{O}_{2}\right)$ fuel cells at temperatures of $25-55^{\circ} \mathrm{C}$. Polarization curves have been recorded with the aim to evaluate the fuel cell performance using the prepared $\mathrm{CoB}$ and that modified with Pt crystallites as the anode catalysts.

For all catalysts (pure $\mathrm{CoB}$ and $\mathrm{PtCoB}$ ) investigated, the peak power density values increase consecutively with the increment in temperature from $25^{\circ} \mathrm{C}$ up to $55^{\circ} \mathrm{C}$. The values from $86-146 \mathrm{mV} \mathrm{cm}^{-2}$ and $146-234 \mathrm{mV} \mathrm{cm}^{-2}$ were determined for pure $\mathrm{CoB}$ and $\mathrm{PtCoB}$ catalysts, respectively. The highest specific peak power density of $21.5 \mathrm{kWg}_{\mathrm{Pt}}{ }^{-1}$ was achieved at $55^{\circ} \mathrm{C}$ temperature when the PtCoB catalyst with the Pt loading of $9.8 \mu \mathrm{g}_{\mathrm{Pt}} \mathrm{cm}^{-2}$ was employed as the anode catalyst in the $\mathrm{NaBH}_{4} / \mathrm{H}_{2} \mathrm{O}_{2}$ single fuel cell.

Keywords: $\mathrm{Pt}, \mathrm{CoB}$, morpholine borane, fuel cell, $\mathrm{NaBH}_{4} / \mathrm{H}_{2} \mathrm{O}_{2}$

\section{INTRODUCTION}

Search of alternative energy sources is getting more and more active when the traditional energy resources are decreasing. Fuel cells are environment-friendly energy sources, in which the chemical energy is turned into the electrical one [1]-3]. They are intensively investigated as cleaner power generators compared to fossil fuel-based technologies. The borohydride fuel cell, which uses an alkaline fuel cell system fed with an aqueous solution of (usually sodium) borohydride $\left(\mathrm{NaBH}_{4}\right)$ and oxygen as an oxidant (DBFC, $\mathrm{NaBH}_{4} / \mathrm{O}_{2}$ ),

\footnotetext{
* Corresponding author. Email: balciunaite.aldona@gmail.com
}

has recently proven to be of a great interest, as it displays a high theoretical specific energy density (9.3 $\mathrm{Wh} \mathrm{g}^{-1}$ ) [4, 5]. Operating of DBFC is based on the ongoing reactions at the anode and cathode, e.g. oxidation of sodium borohydride and reduction of oxygen, respectively. At the anode of the fuel cell, sodium borohydride is oxidized according to Eq. 1:

$$
\begin{aligned}
& \mathrm{BH}_{4}{ }^{-}+8 \mathrm{OH}^{-} \rightarrow \mathrm{BO}_{2}{ }^{-}+6 \mathrm{H}_{2} \mathrm{O}+8 \mathrm{e}^{-}, \\
& E_{\mathrm{a}}^{0}=-1.24 \mathrm{~V} \text { vs SHE. }
\end{aligned}
$$

At the cathode of the same fuel cell, oxygen is reduced according to Eq. 2: 


$$
\begin{aligned}
& 2 \mathrm{O}_{2}+4 \mathrm{H}_{2} \mathrm{O}+8 \mathrm{e}^{-} \rightarrow 8 \mathrm{OH}^{-}, \\
& E_{\mathrm{c}}^{0}=+0.40 \mathrm{~V} \text { vs SHE. }
\end{aligned}
$$

The overall cell reaction in DBFC is

$$
\mathrm{BH}_{4}^{-}+2 \mathrm{O}_{2} \rightarrow \mathrm{BO}_{2}^{-}+2 \mathrm{H}_{2} \mathrm{O}, E_{\text {cell }}^{0}=+1.64 \mathrm{~V} \text {. }
$$

Furthermore, the $\mathrm{NaBH}_{4} / \mathrm{O}_{2}$ fuel cell exhibits a higher theoretical voltage of $1.64 \mathrm{~V}$ (Eq. 3), compared with that of fuel cell systems, such as $\mathrm{CH}_{3} \mathrm{OH} /$ $\mathrm{O}_{2}(1.19 \mathrm{~V}), \mathrm{H}_{2} / \mathrm{O}_{2}(1.23 \mathrm{~V}), \mathrm{HCOOH} / \mathrm{O}_{2}(1.45 \mathrm{~V})$, and $\mathrm{N}_{2} \mathrm{H}_{4} / \mathrm{O}_{2}(1.56 \mathrm{~V})$ [ 6 . The use of hydrogen peroxide $\left(\mathrm{H}_{2} \mathrm{O}_{2}\right)$ in the both alkaline and acidic media as an oxidant in the DBFC system (named as $\mathrm{NaBH}_{4}$ / $\mathrm{H}_{2} \mathrm{O}_{2}$ ) increases the theoretical cell voltage and specific energy density of this fuel cell as compared with those of the $\mathrm{NaBH}_{4} / \mathrm{O}_{2}$ fuel cell [6]. Since the electrochemical reduction of $\mathrm{H}_{2} \mathrm{O}_{2}$ proceeds without formation of poisonous products, the use of $\mathrm{H}_{2} \mathrm{O}_{2}$ as an oxidant in the fuel cells is attractive for further research. The reduction of $\mathrm{H}_{2} \mathrm{O}_{2}$ in an alkaline medium at the cathode of the $\mathrm{NaBH}_{4} / \mathrm{O}_{2}$ fuel cell is given in Eq. 4 [7], and, therefore, the overall cell reaction can be written as Eq. 5:

$$
\begin{aligned}
& 4 \mathrm{HO}_{2}^{-}+4 \mathrm{H}_{2} \mathrm{O}+8 \mathrm{e}^{-} \rightarrow 12 \mathrm{OH}^{-}, \\
& E^{0}=0.87 \mathrm{~V} \text { vs SHE; } \\
& 4 \mathrm{HO}_{2}^{-}+\mathrm{BH}_{4}^{-} \rightarrow 4 \mathrm{OH}^{-}+\mathrm{BO}_{2}^{-}+2 \mathrm{H}_{2} \mathrm{O}, \\
& E_{0}=2.11 \mathrm{~V} .
\end{aligned}
$$

In acidic media, the reduction of $\mathrm{H}_{2} \mathrm{O}_{2}$ at the cathode of fuel cell occurs according to Eq. 6:

$$
\begin{aligned}
& 4 \mathrm{H}_{2} \mathrm{O}_{2}+4 \mathrm{H}^{+}+8 \mathrm{e}^{-} \rightarrow 8 \mathrm{H}_{2} \mathrm{O}, \\
& E_{\mathrm{c}}^{0}=+1.77 \mathrm{~V} \text { vs SHE. }
\end{aligned}
$$

The overall cell reaction in this situation provides a theoretical cell potential of $3.01 \mathrm{~V}$ according to Eq. 7:

$$
\begin{aligned}
& \mathrm{BH}_{4}^{-}+4 \mathrm{H}_{2} \mathrm{O}_{2} \rightarrow \mathrm{BO}_{2}^{-}+6 \mathrm{H}_{2} \mathrm{O}, \\
& E_{\text {cell }}^{0}=+3.01 \mathrm{~V} .
\end{aligned}
$$

The theoretical cell voltage of the $\mathrm{NaBH}_{4} / \mathrm{H}_{2} \mathrm{O}_{2}$ fuel cell when $\mathrm{H}_{2} \mathrm{O}_{2}$ is used in both the alkaline and acidic media as an oxidant is 2.11 and $3.01 \mathrm{~V}$, respectively, which is almost 0.5 and $1.4 \mathrm{~V}$ higher than that of the $\mathrm{NaBH}_{4} / \mathrm{O}_{2}$ fuel cell $(1.64 \mathrm{~V})$ [ $[7]$.

Electrocatalysts have an important role in the performance of $\mathrm{NaBH}_{4} / \mathrm{O}_{2}$ and $\mathrm{NaBH}_{4} / \mathrm{H}_{2} \mathrm{O}_{2}$ fuel cells $[8-30]$. The efficiency of the catalyst depends on different parameters, e.g. on the nature of the substrate, the composition of the catalysts and the size of the nanoparticles formed. The main attention is paid to the search of new nanostructured substances, which will be able to increase the performance of fuel cells. In the past years the researchers have explored different metals as anode catalysts in the fuel cells. It is well known that the use of Pt [10, 13, 14, 16, 17, 19-24] and Au [18, 25-29] alloys catalysts enhances the technological performance of the $\mathrm{NaBH}_{4} / \mathrm{H}_{2} \mathrm{O}_{2}$ fuel cell, however, the noble metal catalysts make it relatively expensive. Therefore, many researchers have been interested in exploring lower-cost substitutes. It was shown that the Pt or Au composites with transition metals, e.g. $\mathrm{Co}, \mathrm{Ni}, \mathrm{Cu}$ and $\mathrm{Fe}$, have demonstrated higher activity and stability for the oxidation of sodium borohydride than the pure Pt or Au catalysts [8, 13, 14, 20-29]. In our previous study [19] it was shown that the $\mathrm{CoB}$ catalysts modified with small amounts of Pt crystallites in the range of ca. $10-14 \mu_{\mathrm{Pt}} \mathrm{cm}^{-2}$ exhibit a high electrocatalytic activity for the electrooxidation of sodium borohydride. The catalysts were prepared using the electroless metal plating and galvanic displacement methods. In the present study, we investigated the performance of the sodium borohydride-hydrogen peroxide $\left(\mathrm{NaBH}_{4} /\right.$ $\mathrm{H}_{2} \mathrm{O}_{2}$ ) fuel cell at different temperatures by employing the $\mathrm{CoB}$ catalysts modified with small amounts of Pt crystallites as the anode material.

\section{EXPERIMENTAL}

\section{Fabrication and characterization of catalysts}

The catalysts of $\mathrm{CoB}$ and that modified with small amounts of $\mathrm{Pt}$ crystallites (denoted as $\mathrm{PtCoB} /$ $\mathrm{Cu}$ ) were the same as described in our previous study [19]. Briefly, the CoB layers were deposited on the $\mathrm{Cu}$ sheets (denoted as $\mathrm{CoB} / \mathrm{Cu}$ ) with a geometric area of $2 \mathrm{~cm}^{2}$ using morpholine borane $\left(\mathrm{C}_{4} \mathrm{H}_{8} \mathrm{ONH} \cdot \mathrm{BH}_{3}\right)$ as a reducing agent. The electroless cobalt-plating bath consisted of $0.05 \mathrm{M} \mathrm{CoSO}_{4}$ and $0.05 \mathrm{M} \mathrm{C}_{4} \mathrm{H}_{8} \mathrm{ONH} \cdot \mathrm{BH}_{3}$. The bath operated at 
$\mathrm{pH} 7$ and at $30^{\circ} \mathrm{C}$ temperature. The deposition time of the $\mathrm{CoB}$ layers on the $\mathrm{Cu}$ sheets was $100 \mathrm{~min}$. Then, the galvanic displacement method was used for the deposition of $\mathrm{Pt}$ crystallites on the $\mathrm{CoB}$ surface [19]. Dipping of the prepared $\mathrm{CoB} / \mathrm{Cu}$ electrodes into the $1 \mathrm{mM} \mathrm{H}_{2} \mathrm{PtCl}_{6}$ solution for 10,30 and $60 \mathrm{~s}$ results in the deposition of Pt crystallites of $\sim 10-25,20-35$, and $20-45 \mathrm{~nm}$, respectively, on the surface of $\mathrm{CoB} / \mathrm{Cu}$. It was found that the $\mathrm{PtCoB} /$ $\mathrm{Cu}$ catalysts were prepared with Pt loadings of 9.8, 10.6 and $14.4 \mu \mathrm{g}_{\mathrm{pt}} \mathrm{cm}^{-2}$. The prepared catalysts were used as the anodes for direct $\mathrm{NaBH}_{4} / \mathrm{H}_{2} \mathrm{O}_{2}$ fuel cell test measurements without any further treatment.

\section{Fuel cell test experiments}

Single fuel cell tests were carried out in the lab-scale $\mathrm{NaBH}_{4} / \mathrm{H}_{2} \mathrm{O}_{2}$ by employing the prepared $\mathrm{CoB} / \mathrm{Cu}$ or $\mathrm{PtCoB} / \mathrm{Cu}$ electrodes as the anodes and a $\mathrm{Pt}$ sheet as the cathode. Each compartment of the cell contained $100 \mathrm{~mL}$ of a static electrolyte solution, with the anolyte containing $1 \mathrm{M} \mathrm{NaBH}_{4}+4 \mathrm{M} \mathrm{NaOH}$ and the catholyte containing $1.5 \mathrm{M} \mathrm{HCl}+5 \mathrm{M} \mathrm{H}_{2} \mathrm{O}_{2}$. A Nafion N117 membrane was used to separate the anodic and cathodic compartments of the single direct $\mathrm{NaBH}_{4} / \mathrm{H}_{2} \mathrm{O}_{2}$ fuel cell [11]. Cell measurements were conducted using a Zennium electrochemical workstation (ZAHNER-Elektrik GmbH \& Co. KG). The performance of the fuel cell was evaluated by recording the cell polarization curves and obtaining the corresponding power density curves at $25-55^{\circ} \mathrm{C}$ temperatures.

\section{RESULTS AND DISCUSSION}

In the present study, the performance of a direct alkaline $\mathrm{NaBH}_{4} / \mathrm{H}_{2} \mathrm{O}_{2}$ single fuel cell has been investigated by using the catalysts of $\mathrm{CoB}$ and $\mathrm{CoB}$ modified with small amounts of Pt crystallites as the anode materials. The low-cost electroless metal deposition and galvanic displacement methods were used for the preparation of the $\mathrm{CoB} / \mathrm{Cu}$ and $\mathrm{PtCoB} / \mathrm{Cu}$ catalysts. Figure 1 presents the fuel cell polarization curves and the corresponding power density curves against the current density by employing the $\mathrm{CoB} / \mathrm{Cu}$ as the anode catalyst at $25-55^{\circ} \mathrm{C}$ temperatures. The fuel cell displayed an open circuit voltage of ca. 1.8 V. As seen, peak power density values increase with the increase in temperature from 25 up to $55^{\circ} \mathrm{C}$. The obtained values ranged from 86 to $145 \mathrm{~mW} \mathrm{~cm}^{-2}$ for the $\mathrm{CoB} /$ $\mathrm{Cu}$ catalyst used as the anode in the $\mathrm{NaBH}_{4} / \mathrm{H}_{2} \mathrm{O}_{2}$ single fuel cell (Fig. 1).

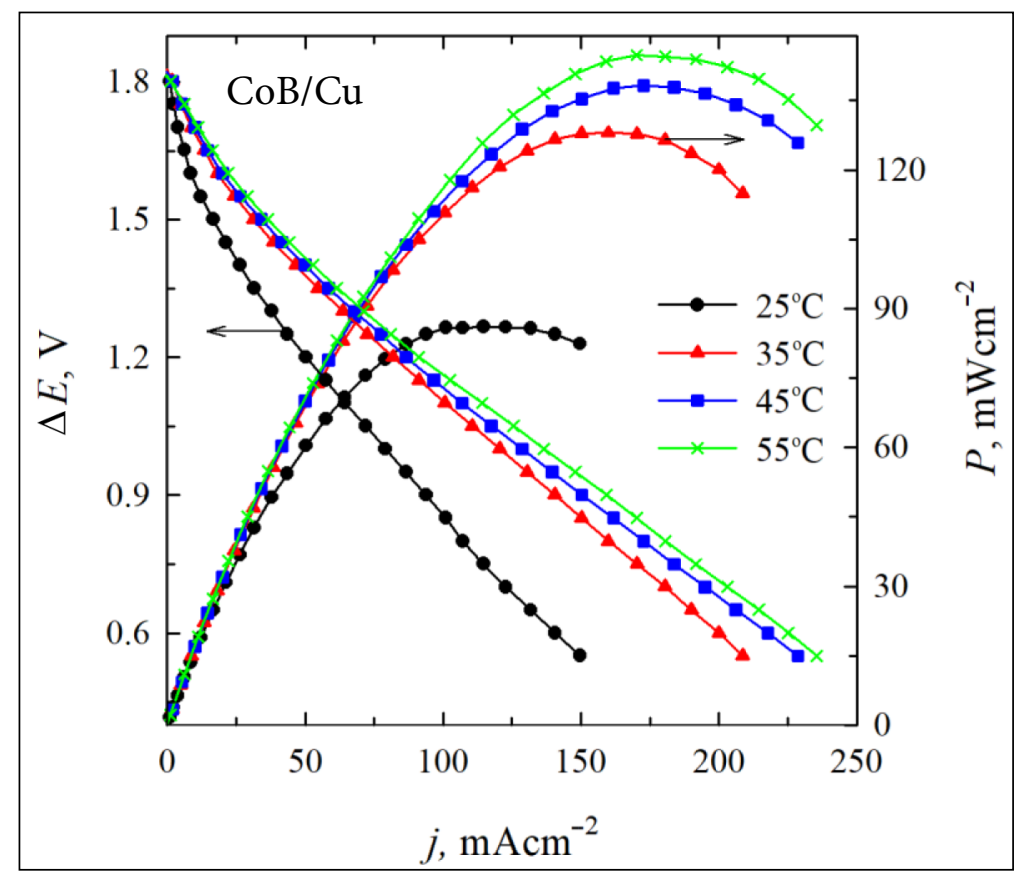

Fig. 1. Cell polarization and power density curves for the $\mathrm{NaBH}_{4} / \mathrm{H}_{2} \mathrm{O}_{2}$ single fuel cell using the $\mathrm{CoB} / \mathrm{Cu}$ catalysts as the anodes with the anolyte consisting of the $1 \mathrm{M} \mathrm{NaBH}_{4}+4 \mathrm{M} \mathrm{NaOH}$ and $5 \mathrm{M} \mathrm{H}_{2} \mathrm{O}_{2}+1.5 \mathrm{M} \mathrm{HCl}$ catholyte and operation temperatures ranging from 25 to $55^{\circ} \mathrm{C}$ 
The fuel cell polarization curves and the corresponding power density curves against the current density by employing different $\mathrm{PtCoB} / \mathrm{Cu}$ catalysts as the anode catalysts at $25-55^{\circ} \mathrm{C}$ temperatures in the range of $25-55^{\circ} \mathrm{C}$ are shown in Fig. 2 . The summarized data are given in Table 1 . The fuel cell displayed an open circuit voltage of ca. $1.9 \mathrm{~V}$. The highest peak power densities of 211, 222 and $234 \mathrm{~mW} \mathrm{~cm}^{-2}$ are achieved at $55^{\circ} \mathrm{C}$ temperature when employing the $\mathrm{PtCoB} / \mathrm{Cu}$ anode catalysts with Pt loadings of 9.8, 10.6 and $14.4 \mu \mathrm{g}_{\mathrm{Pt}} \mathrm{cm}^{-2}$, respectively. The measured peak power densities of the $\mathrm{NaBH}_{4} / \mathrm{H}_{2} \mathrm{O}_{2}$ fuel cell with different $\mathrm{PtCoB} / \mathrm{Cu}$ anodes are increased with the increase in the temperature from 25 to $55^{\circ} \mathrm{C}$. The values obtained ranged from 146 to $234 \mathrm{~mW} \mathrm{~cm}^{-2}$ for the $\mathrm{PtCoB} /$ $\mathrm{Cu}$ catalysts with the $\mathrm{Pt}$ loading ranging from 9.8 to $14.4 \mu \mathrm{g}_{\mathrm{Pt}} \mathrm{cm}^{-2}$. It has been determined that power density values are significantly higher in the case of the investigated $\mathrm{PtCoB} / \mathrm{Cu}$ catalysts as compared to those of pure $\mathrm{CoB} / \mathrm{Cu}$ (Figs. 1, 2).

Peak power densities at $25^{\circ} \mathrm{C}$ temperature for $\mathrm{PtCoB} / \mathrm{Cu}$ with the $\mathrm{Pt}$ loadings of $9.8,10.6$ and $14.4 \mu \mathrm{g}_{\mathrm{Pt}} \mathrm{cm}^{-2}$ were ca. 1.7, 1.9 and 2.0 , respectively, times higher as compared with those of pure $\mathrm{CoB} / \mathrm{Cu}$. Ca. 1.4, 2.6 and 2.7 times higher peak power densities of the $\mathrm{NaBH}_{4} / \mathrm{H}_{2} \mathrm{O}_{2}$ fuel cell at $55^{\circ} \mathrm{C}$ temperature were obtained on the $\mathrm{PtCoB} / \mathrm{Cu}$ with the Pt loadings of 9.8, 10.6 and $14.4 \mu \mathrm{g}_{\mathrm{Pt}} \mathrm{cm}^{-2}$, respectively, compared with those for $\mathrm{CoB} / \mathrm{Cu}$.

For evaluation of the activity of the prepared $\mathrm{PtCoB} / \mathrm{Cu}$ catalysts used as the anodes in the $\mathrm{NaBH}_{4} / \mathrm{H}_{2} \mathrm{O}_{2}$ fuel cell, the power density values were normalized by the Pt loadings for each catalyst. The obtained values represent the specific power densities, i.e. power density per gram of $\mathrm{Pt}$ in the $\mathrm{PtCoB} / \mathrm{Cu}$ catalysts. The summarized data are given in Table 1 and Fig. 3. It can be observed that the $\mathrm{NaBH}_{4} / \mathrm{H}_{2} \mathrm{O}_{2}$ fuel cell, in which the $\mathrm{PtCoB} / \mathrm{Cu}$ catalysts with different Pt loadings were employed as the anodes, produces from 12.3 to $14.9 \mathrm{~kW} \mathrm{~g}_{\mathrm{Pt}}{ }^{-1}$ specific power densities at room temperature $\left(25^{\circ} \mathrm{C}\right)$, whereas from 16.3 to $21.5 \mathrm{~kW} \mathrm{~g} \mathrm{gt}_{\mathrm{Pt}}{ }^{-1}$ at $55^{\circ} \mathrm{C}$ temperature (Fig. 3 ).

Comparison of the operation parameters of the $\mathrm{NaBH}_{4} / \mathrm{H}_{2} \mathrm{O}_{2}$ fuel cell with the employed anode $\mathrm{CoB} / \mathrm{Cu}$ and $\mathrm{PtCoB} / \mathrm{Cu}$ catalysts prepared in this study and those presented in literature, such as PtM-based [10, 21, 23, 24] or AuM-based [18, 25] electrodes, is summarized in Table 2. It is clearly

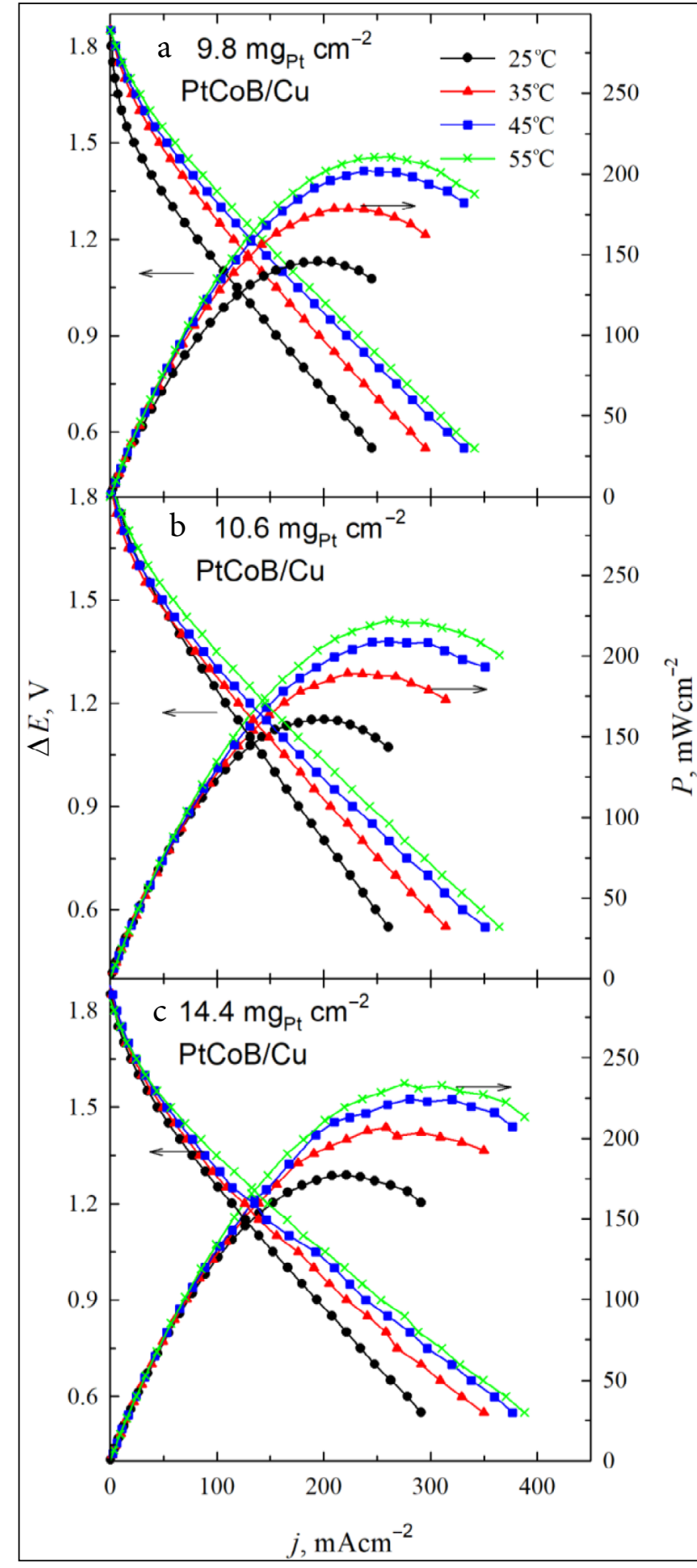

Fig. 2. Cell polarization and power density curves for the $\mathrm{NaBH}_{4} / \mathrm{H}_{2} \mathrm{O}$, single fuel cell using the $\mathrm{PtCOB} / \mathrm{Cu}$ catalysts with the Pt loading of 9.8 (a), 10.6 (b) and 14.4 (c) $\mu g_{\mathrm{Pt}} \mathrm{cm}^{-2}$ as the anodes with the anolyte consisting of the $1 \mathrm{M} \mathrm{NaBH}_{4}+4 \mathrm{M} \mathrm{NaOH}$ and $5 \mathrm{M} \mathrm{H}_{2} \mathrm{O}_{2}+1.5 \mathrm{M} \mathrm{HCl}$ catholyte and operation temperatures ranging from 25 to $55^{\circ} \mathrm{C}$

seen that the power density output and specific power density of the $\mathrm{NaBH}_{4} / \mathrm{H}_{2} \mathrm{O}_{2}$ fuel cell using the investigated $\mathrm{CoB} / \mathrm{Cu}$ catalysts modified with small amounts of Pt crystallites as the anodes are significantly higher than those of PtM $(\mathrm{M}=\mathrm{Ni}$, 
Table 1. Fuel cell parameters of the $\mathrm{NaBH}_{4} / \mathrm{H}_{2} \mathrm{O}_{2}$ single fuel cell employing the $\mathrm{CoB} / \mathrm{Cu}$ and $\mathrm{PtCoB} / \mathrm{Cu}$ anode catalysts

\begin{tabular}{|c|c|c|c|c|c|c|}
\hline$T,{ }^{\circ} \mathrm{C}$ & Catalysts & $\begin{array}{l}\text { Pt loading, } \\
\mu \mathrm{g} \mathrm{cm}^{-2}\end{array}$ & $\begin{array}{l}\text { Peak power density, } \\
\qquad \mathrm{mW} \mathrm{cm}\end{array}$ & $\begin{array}{l}\text { Current density at peak } \\
\text { power density, } \mathrm{mA} \mathrm{cm} \mathrm{cm}^{-2}\end{array}$ & $\begin{array}{l}\text { Cell voltage at peak } \\
\text { power density, V }\end{array}$ & $\begin{array}{l}\text { Specific peak power } \\
\text { density, } \mathbf{k W ~ g ~}_{\mathrm{pt}}{ }^{-1}\end{array}$ \\
\hline 25 & \multirow{4}{*}{$\mathrm{CoB} / \mathrm{Cu}$} & \multirow{4}{*}{-} & 86.0 & 114.7 & 0.75 & - \\
\hline 35 & & & 128.0 & 160.0 & 0.80 & - \\
\hline 45 & & & 138.3 & 172.8 & 0.80 & - \\
\hline 55 & & & 144.8 & 170.3 & 0.85 & - \\
\hline 25 & \multirow{12}{*}{$\mathrm{PtCoB} / \mathrm{Cu}$} & \multirow{4}{*}{9.8} & 145.8 & 194.3 & 0.75 & 14.9 \\
\hline 35 & & & 178.5 & 209.9 & 0.85 & 18.2 \\
\hline 45 & & & 201.9 & 237.4 & 0.85 & 20.6 \\
\hline 55 & & & 210.5 & 263.0 & 0.80 & 21.5 \\
\hline 25 & & \multirow{4}{*}{10.6} & 160.5 & 200.6 & 0.80 & 15.1 \\
\hline 35 & & & 189.2 & 222.4 & 0.85 & 17.8 \\
\hline 45 & & & 209.0 & 261.2 & 0.80 & 19.7 \\
\hline 55 & & & 222.4 & 261.5 & 0.85 & 21.0 \\
\hline 25 & & \multirow{4}{*}{14.4} & 177.0 & 221.2 & 0.80 & 12.3 \\
\hline 35 & & & 206.7 & 258.3 & 0.80 & 14.4 \\
\hline 45 & & & 224.4 & 280.5 & 0.80 & 15.6 \\
\hline 55 & & & 234.3 & 275.5 & 0.85 & 16.3 \\
\hline
\end{tabular}

Table 2. Operation parameters of the $\mathrm{NaBH}_{4} / \mathrm{H}_{2} \mathrm{O}_{2}$ fuel cell using different anode catalysts

\begin{tabular}{|c|c|c|c|c|c|c|c|c|}
\hline Anode & Cathode & 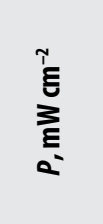 & 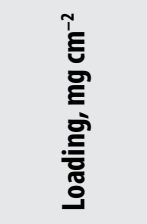 & 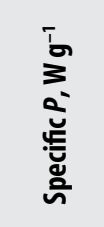 & Anolyte & Catholyte & 品 & Ref. \\
\hline $\mathrm{CoB} / \mathrm{Cu}$ & \multirow{4}{*}{$\mathrm{Pt}$} & 86.0 & - & - & \multirow{4}{*}{$\begin{array}{c}1 \mathrm{M} \\
\mathrm{NaBH}_{4}+4 \mathrm{M} \mathrm{NaOH}\end{array}$} & \multirow{4}{*}{$\begin{array}{c}5 \mathrm{M} \\
\mathrm{H}_{2} \mathrm{O}_{2}+1.5 \mathrm{M} \mathrm{HCl}\end{array}$} & \multirow{4}{*}{25} & \multirow{4}{*}{$\begin{array}{l}\text { This } \\
\text { work }\end{array}$} \\
\hline \multirow{3}{*}{$\mathrm{PtCoB} / \mathrm{Cu}$} & & 145.8 & $\begin{array}{c}0.0098 \\
\mathrm{mg}_{\mathrm{Pt}} \mathrm{Cm}^{-2}\end{array}$ & 14900 & & & & \\
\hline & & 160.5 & $\begin{array}{c}0.0104 \\
\mathrm{mg}_{\mathrm{pt}} \mathrm{Cm}^{-2}\end{array}$ & 15100 & & & & \\
\hline & & 177.0 & $\begin{array}{c}0.0144 \\
\mathrm{mg}_{\mathrm{pt}} \mathrm{Cm}^{-2}\end{array}$ & 12300 & & & & \\
\hline $\mathrm{NiPt} / \mathrm{C}$ & $\begin{array}{c}\mathrm{Pt} / \mathrm{C} \\
0.5 \mathrm{mg} \mathrm{cm}^{-2}\end{array}$ & 60.10 & 1 & 60 & $\begin{array}{c}2 \mathrm{M} \\
\mathrm{NaBH}_{4}+2 \mathrm{M} \mathrm{NaOH}\end{array}$ & $\begin{array}{c}2 \mathrm{M} \\
\mathrm{H}_{2} \mathrm{O}_{2}+0.5 \mathrm{M} \mathrm{H}_{2} \mathrm{SO}_{4}\end{array}$ & 25 & {$[10]$} \\
\hline $\mathrm{Pt}_{2} \mathrm{Cu} / \mathrm{NPC}$ & $\mathrm{Au} / \mathrm{XC}-72$ & 89.0 & $\begin{array}{c}0.024 \\
\mathrm{mg}_{\mathrm{Pt}} \mathrm{cm}^{-2}\end{array}$ & 3708 & $\begin{array}{c}1 \mathrm{M} \\
\mathrm{NaBH}_{4}+3 \mathrm{M} \mathrm{NaOH}\end{array}$ & $\begin{array}{c}2 \mathrm{M} \\
\mathrm{H}_{2} \mathrm{O}_{2}+0.5 \mathrm{M} \mathrm{H}_{2} \mathrm{SO}_{4}\end{array}$ & 25 & {$[24]$} \\
\hline $\mathrm{Pt}_{67} \mathrm{Co}_{33} / \mathrm{C}$ & $\begin{array}{c}\mathrm{Pt} / \mathrm{C} \\
0.9 \mathrm{mg} \mathrm{cm}^{-2}\end{array}$ & 79.7 & 0.9 & 114 & $\begin{array}{c}1 \mathrm{M} \\
\mathrm{NaBH}_{4}+3 \mathrm{M} \mathrm{NaOH}\end{array}$ & $\begin{array}{c}2 \mathrm{M} \\
\mathrm{H}_{2} \mathrm{O}_{2}+0.5 \mathrm{M} \mathrm{H}_{2} \mathrm{SO}_{4}\end{array}$ & 25 & {$[21]$} \\
\hline $\mathrm{PtNi} / \mathrm{G}$ & $\begin{array}{c}\mathrm{Pt} / \mathrm{G} \\
0.5 \mathrm{mg} \mathrm{cm}^{-2}\end{array}$ & 60.4 & 1 & 60 & $\begin{array}{c}1 \mathrm{M} \\
\mathrm{NaBH}_{4}+2 \mathrm{M} \mathrm{NaOH}\end{array}$ & $\begin{array}{c}2 \mathrm{M} \\
\mathrm{H}_{2} \mathrm{O}_{2}+0.5 \mathrm{M} \mathrm{H}_{2} \mathrm{SO}_{4} \\
\end{array}$ & 60 & {$[23]$} \\
\hline $\mathrm{Au}_{45} \mathrm{Co}_{55} / \mathrm{C}$ & $\mathrm{Au} / \mathrm{C}$ & 66.5 & 4.5 & 73.9 & $\begin{array}{c}1 \mathrm{M} \\
\mathrm{NaBH}_{4}+3 \mathrm{M} \mathrm{NaOH}\end{array}$ & $\begin{array}{c}2 \mathrm{M} \\
\mathrm{H}_{2} \mathrm{O}_{2}+0.5 \mathrm{M} \mathrm{H}_{2} \mathrm{SO}_{4}\end{array}$ & 25 & [25] \\
\hline Au@Co-B & $\mathrm{LaNi}_{0.9} \mathrm{Ru}_{0.1} \mathrm{O}_{3}$ & 85.0 & 0.7 & 121 & $\begin{array}{r}0.8 \mathrm{M} \mathrm{KBF} \\
\text { (membranel }\end{array}$ & $\begin{array}{l}6 \mathrm{M} \mathrm{KOH} \\
\text {, air cathode) }\end{array}$ & 25 & {$[18]$} \\
\hline
\end{tabular}




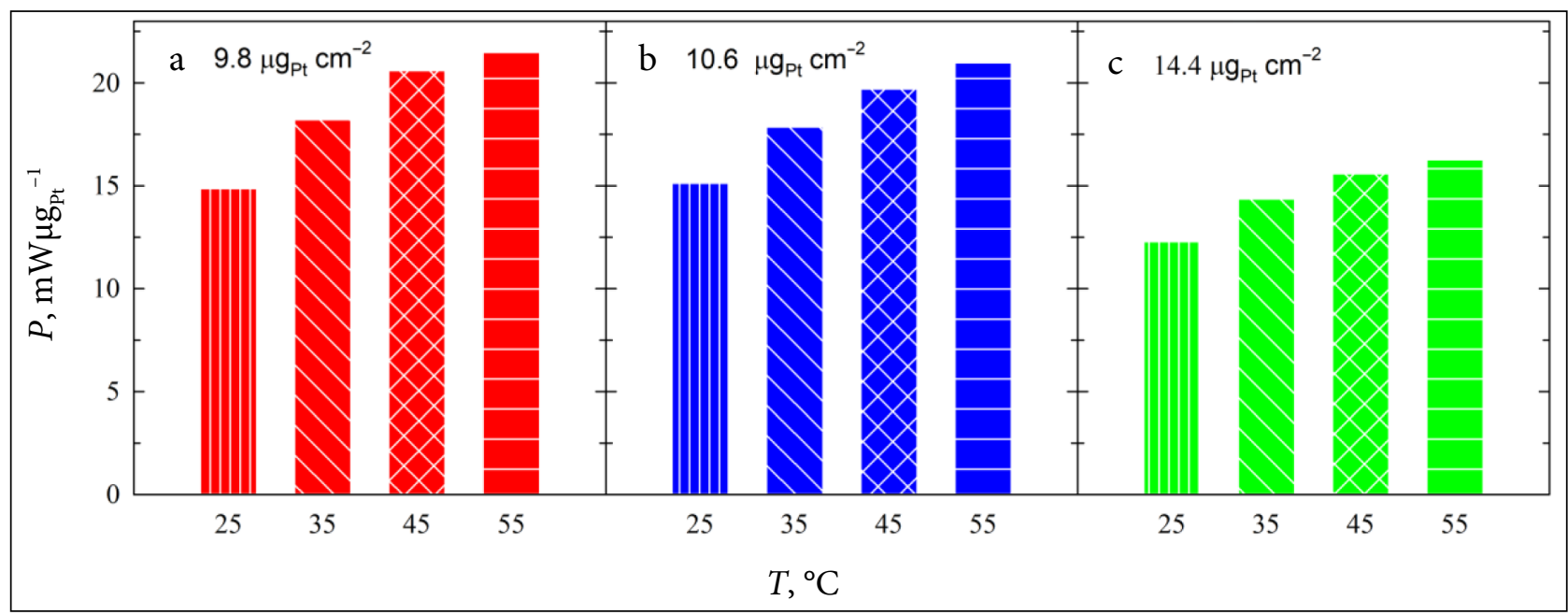

Fig. 3. The dependence of specific peak power densities of the $\mathrm{NaBH}_{4} / \mathrm{H}_{2} \mathrm{O}_{2}$ fuel cell on temperature by using the PtCoB/Cu catalysts with the Pt loadings of 9.8 (a), 10.6 (b) and 14.4 (c) $\mu \mathrm{g}_{\mathrm{pt}} \mathrm{cm}^{-2}$

$\mathrm{Co}, \mathrm{Cu})[10,21,23,24]$ or AuCo [18, 25] used as the anode catalysts (Table 2 ).

The decoration of the $\mathrm{CoB} / \mathrm{Cu}$ electrodes with small amounts of $\mathrm{Pt}$ crystallites in the range of 9-14 $\mu \mathrm{g}_{\mathrm{Pt}} \mathrm{cm}^{-2}$ significantly enhances the performance of the $\mathrm{NaBH}_{4} / \mathrm{H}_{2} \mathrm{O}_{2}$ fuel cell and seems to be promising anode materials for it.

\section{CONCLUSIONS}

The CoB and PtCoB catalysts formed by means of electroless cobalt deposition and galvanic displacement by Pt were tested as the anodes for the direct borohydride-hydrogen peroxide fuel cell. The assembled $\mathrm{NaBH}_{4} / \mathrm{H}_{2} \mathrm{O}_{2}$ fuel cells using the $\mathrm{CoB}$ and $\mathrm{PtCoB}$ catalysts with the Pt loading in the range of ca. $10-14 \mu \mathrm{g}_{\mathrm{Pt}} \mathrm{cm}$ as the anodes exhibit an open circuit voltage of ca. 1.8-1.9 V. For all catalysts investigated (pure $\mathrm{CoB}$ and $\mathrm{PtCoB}$ ), the peak power density values increase consecutively with the increment in temperature from $25^{\circ} \mathrm{C}$ up to $55^{\circ} \mathrm{C}$. The values from $86-146 \mathrm{mV} \mathrm{cm}^{-2}$ and $146-234 \mathrm{mV} \mathrm{cm}^{-2}$ were determined for the pure $\mathrm{CoB}$ and $\mathrm{PtCoB}$ catalysts, respectively. The decoration of the $\mathrm{CoB} / \mathrm{Cu}$ electrodes with small amounts of $\mathrm{Pt}$ significantly enhances the performance of the $\mathrm{NaBH}_{4} / \mathrm{H}_{2} \mathrm{O}_{2}$ fuel cell. The highest peak power density up to $177 \mathrm{~mW} \mathrm{~cm} \mathrm{~cm}^{-2}$ at room temperature has been obtained with the $\mathrm{CoB} / \mathrm{Cu}$ catalyst, which has the Pt loading of $14.4 \mu \mathrm{g}_{\mathrm{Pt}} \mathrm{cm}^{-2}$. Furthermore, the greatest specific peak power density of $21.5 \mathrm{~kW} \mathrm{~g}_{\mathrm{Pt}}{ }^{-1}$ has been obtained on the $\mathrm{PtCoB} /$ $\mathrm{Cu}$ anode catalyst with the Pt loading of $9.8 \mu \mathrm{g}_{\mathrm{Pt}} \mathrm{cm}^{-2}$ at $55^{\circ} \mathrm{C}$ temperature.

\section{ACKNOWLEDGEMENTS}

This research was funded by a grant (No. M-ERA. NET-1/2016) from the Research Council of Lithuania.

Received 5 September 2018 Accepted 3 October 2018

\section{References}

1. J. Larminie, A. Dicks, Fuel Cell Systems Explained, 2nd edn., p. 156, John Wiley \& Sons Ltd. (2003).

2. C. Rayment, S. Sherwin, Introduction to Fuel Cell Technology, p. 433, University of Notre Dame, USA (2003).

3. Fuel Cell Handbook, 7th edn., p. 427, EG\&G Technical Services, Inc., Morgantown, West Virginia (2004).

4. V. Kiran, S. Srinivasan, J. Ind. Inst. Sci., 89, 447 (2009).

5. D. M. F. Santos, C. A. C. Sequeira, Renew. Sustain. Energy Rev., 15, 3980 (2011).

6. T. H. Oh, B. Jang, S. Kwon, Energy, 90, 980 (2015).

7. C. Ponce de Leon, F. C. Walsh, A. Rose, J. B. Lakeman, D. J. Browning, R. W. Reeve, J. Power Sources, 164, 441 (2007).

8. X. Y. Geng, H. M. Zhang, W. Ye, Y. W. Ma, H. X. Zhong, J. Power Sources, 185, 627 (2008).

9. H. Y. Qin, Z. X. Liu, L. Q. Ye, J. K. Zhu, Z. P. Li, J. Power Sources, 192, 385 (2009).

10. M. G. Hosseini, R. Mahmoodi, M. S. Amjadi, Energy, 131, 137 (2017).

11. A. Balčiūnaitè, Z. Sukackienè, L. TamašauskaitèTamašiūnaitė, D. M. F. Santos, E. Norkus, Chemija, 28, 21 (2017).

12. K. Ye, F. Guo, Y. Gao, et al., J. Power Sources, 300, 147 (2015). 
13. D. S. P. Cardoso, D. M. F. Santos, B. Šljukić, C. A. C. Sequeira, D. Macciò, A. Saccone, J. Power Sources, 307, 251 (2016).

14. M. G. Hosseini, R. Mahmoodi, Int. J. Hydrogen Energy, 42, 10363 (2017).

15. C. Song, D. Zhang, K. Ye, et al., J. Electroanal. Chem., 788, 74 (2017).

16. A. Tegou, S. Papadimitriou, I. Mintsouli, et al., Catal. Today, 170, 126 (2011).

17. L. Tamašauskaitè-Tamašiūnaitè, A. Radomskis, K. Antanavičiūte, et al., Int. J. Hydrogen Energy, 39, 4282 (2014).

18. S. Li, L. Wang, J. Chu, H. Zhu, Y. Chen, Y. Liu, Int. J. Hydrogen Energy, 41, 8583 (2016).

19. A. Balčiūnaitè, Z. Sukackienè, L. TamašauskaitèTamašiūnaitė, Ž. Činčienè, A. Selskis, E. Norkus, Electrochim. Acta, 225, 255 (2017).

20. L. Xue, Y. Lanhua, W. Xianyou, S. Jincang, S. Yunfeng, L. Jing, Int. J. Hydrogen Energy, 37, 17984 (2012).

21. L. Yi, L. Liu, X. Liu, et al., Int. J. Hydrogen Energy, 37, 12650 (2012).

22. K. Ye, D. Zhang, H. Zhang, K. Cheng, G. Wang, D. Cao, Electrochim. Acta, 178, 270 (2015).

23. M. G. Hosseini, N. Rashidi, R. Mahmoodi, M. Omer, Mat. Chem. Phys., 208, 207 (2018).

24. J. Liu, Q. Zhao, S. Chen, L. Yi, X. Wang, W. Wei, Electrochim. Acta., 171, 96 (2015).

25. F. Pei, Y. Wang, X. Wang, et al., Int. J. Hydrogen Energy, 35, 8136 (2010).

26. K. Ye, D. Zhang, X. Wang, K. Cheng, D. Cao, RSC Adv., 5, 3239 (2015).

27. D. Duan, J. Liang, H. Liu, et al., Int. J. Hydrogen Energy, 40, 488 (2015).

28. L. Yi, W. Wei, C. Zhao, L. Tian, J. Liu, X. Wang, J. Power Sources, 285, 325 (2015).

29. D. Duan, H. Liu, X. You, H. Wei, S. Liu, J. Power Sources, 293, 292 (2015).
30. R. C. P. Oliveira, J. Milikic, E. Das, A. B. Yurtcan, D. M. F. Santos, B. Šljukic, Appl. Cat., B, 238, 454 (2018).

Aldona Balčiūnaitè, Zita Sukackienè,

Loreta Tamašauskaitè-Tamašiūnaitè, Rimantas Vaitkus,

Eugenijus Norkus

\section{PLATINOS-KOBALTO-BORO TAIKYMAS KAIP ANODO MEDŽIAGOS NATRIO BOROHIDRIDO- VANDENILIO PEROKSIDO KURO ELEMENTUOSE}

Santrauka

Platinos-kobalto-boro (PtCoB) ir kobalto-boro (CoB) katalizatoriai buvo nusodinti ant vario paviršiaus taikant cheminio metalų nusodinimo ir galvaninio pakeitimo metodus. Suformuoti $\mathrm{PtCoB} / \mathrm{Cu}$ ir $\mathrm{CoB} / \mathrm{Cu}$ katalizatoriai buvo anodais integruojami tiesioginiame natrio borohidrido-vandenilio peroksido $\left(\mathrm{NaBH}_{4} / \mathrm{H}_{2} \mathrm{O}_{2}\right)$ kuro elemente. Pt elektrodas buvo naudojamas katodu. Anolitu pasirinktas $1 \mathrm{M} \mathrm{NaBH}_{4}+4 \mathrm{M} \mathrm{NaOH}$ tirpalas, o katolitu - $5 \mathrm{M} \mathrm{H}_{2} \mathrm{O}_{2}+1,5 \mathrm{M} \mathrm{HCl}$. Kuro elemento parametrų matavimai buvo atlikti esant $25,35,45$ ir $55^{\circ} \mathrm{C}$ temperatūroms. Atviros grandinès sąlygomis celès įtampa yra apie 1,8-1,9 V. Naudojant $\mathrm{PtCoB} / \mathrm{Cu}$ anodo katalizatorius $\mathrm{NaBH}_{4} / \mathrm{H}_{2} \mathrm{O}_{2}$ kuro elemente, kai nusodintos Pt ikrova yra 9,8-14,4 $\mu \mathrm{g}_{\mathrm{Pt}} \mathrm{cm}^{-2}$, buvo gautos didesnès galios tankio vertès, lyginant jas su $\mathrm{CoB} / \mathrm{Cu}$ anodo katalizatoriumi. Didžiausias galios tankis $177 \mathrm{~mW} \mathrm{~cm}^{-2}$ esant $25{ }^{\circ} \mathrm{C}$ temperatūrai, $221 \mathrm{~mA} \mathrm{~cm}^{-2}$ srovès tankiui ir $0,80 \mathrm{~V}$ celès ittampai buvo gautas panaudojant $\mathrm{PtCoB} /$ $\mathrm{Cu}$ katalizatorių su nusodintos Pt ịkrova $14,4 \mu \mathrm{g}_{\mathrm{Pt}} \mathrm{cm}^{-2}$. Didžiausias specifinis galios tankis $21,5 \mathrm{~kW} \mathrm{~g}_{\mathrm{Pt}}{ }^{-1}$ gautas naudojant $\mathrm{PtCoB} / \mathrm{Cu}$ katalizatorių su nusodintos $\mathrm{Pt}$ ikrova $9,8 \mu \mathrm{g}_{\mathrm{Pt}} \mathrm{cm}^{-2}$ esant $55^{\circ} \mathrm{C}$ temperatūrai. 
